\title{
Por uma Teologia Nupcial da Misericórdia \\ O Mistério da Misericórdia a partir do Comentário de Apônio ao Cântico dos Cânticos
}

Orientador: Luiz Fernando Ribeiro Santana

Doutorando: Fabio Magno de Castro Araújo

Área de Concentração: Teologia Sistemático-Pastoral

Linha de Pesquisa: Fé e Cultura

Projeto de Pesquisa: Questões atuais de Teologia Litúrgica

Um olhar atento para toda a história da salvação revela que o fio condutor da mesma é precisamente a misericórdia, que é o principal atributo divino. Trata-se, portanto, de uma temática central para a fé cristã e sua reta compreensão do ponto de vista teológico é de enorme relevância para a pastoral e para a vida espiritual dos discípulos missionários de Jesus Cristo. O nosso enfoque neste tema é feito a partir da Obra aponiana, que apresenta uma originalidade em relação a outros comentários ao Cântico dos Cânticos. De fato, mais do que enfatizar a aliança esponsal entre Deus e o homem, Apônio vê na trama de amor entre os esposos do poema bíblico uma prefiguração da história da salvação. Por se tratar de um autor bastante desconhecido, a primeira parte da nossa pesquisa concentra a sua atenção na figura e na Obra de Apônio, bem como na influência que o seu Comentário exerceu sobre alguns autores posteriores. Em seguida, o nosso enfoque se volta para a hermenêutica do Cântico dos Cânticos, considerando o modo como este livro bíblico foi interpretado tanto pela tradição judaica quanto pelos Padres da Igreja. O objetivo desta parte é relevar as características da exegese aponiana, na qual o nosso autor insere as suas exposições doutrinais e espirituais. Por fim, a nossa tese se debruça sobre o tema escolhido, partindo da Trindade como fonte da misericórdia e enfatizando a ação do Cristo-Esposo misericordioso, o qual, no mistério Pascal desposa para sempre a Igreja, tornando-a "sacramento da misericórdia". Como membro da 
Igreja-Esposa, cada cristão é chamado a experimentar em si mesmo este mistério nupcial e ser testemunha da misericórdia divina.

Palavras-chave: Misericórdia. Mistério. Cântico dos Cânticos. Apônio. Teologia Nupcial. 